\section{Luminous Centipedes.}

With reference to the paragraph in NatuRE of November 23 (p. 233) on luminous centipedes in France, it may be of interest if I mention that these were very frequent in the neighbourhood of Albert and Fricourt in the autumn and winter months a year ago. They appeared to be Geophilus electricus, which I had often seen glowing, particularly on mild, damp evenings in late autumn, in Surrey lanes, and sometimes on garden paths in London suburbs.

As the troops marched across the damp grassland to and from the trenches by night, the spots of phosphorescence on the ground at their feet were taken for glowing match-ends, though one might occasionally hear a man from the country refer to them as "glowworms." I have more than once known an officer get seriously perturbed when troops were marching across a danger zone and the glowing points on the ground seemed evidence that the men were disobeying the "no smoking" order which had been passed along the column!

Luminous centipedes were also to be found in the trenches themselves.

Sutherlands Auxiliary Hospital, Reading, November 27 .

\section{Searchlights.}

Searchlights are now so common that it may be of interest to record that, as might have been expected, the beam shows the presence of polarisation, if it is viewed through a Nicol prism, the line of sight through the prism being perpendicular to the direction of the beam. On rotating the prism, the part of the beam viewed changes its intensity in such a way as to show that the light reflected from it is polarised in a plane passing through the length of the beam and the eye of the observer. The best results occur; of course, when the haze reflecting the beam is thin in character, its particles being small. In such cases the light nearly disappears for a suitable azimuth of the Nicol.

C. T. Whitmell.

Invermay, Hyde Park, Leeds, December I.

\section{Columnar Ice-Crystals.}

AFTER the recent frost a thin layer of gravel became separated from the rest on the paths here (in the park), and on examination was found to be supported by columnar ice-crystals resembling basalt or sal-ammoniac in formation.

The columns were vertical and parallel, closely packed together and of uniform length (about one centimetre).

I should be glad if some reader would kindly explain this (to me) remarkable uniformity.

County School, Merthyr.

A. E. Larkman.

AGRICULTURE AND THE WHEAT SUPPLY. THE present high price of food has directed attention to the urgent need for increasing the production of wheat in this country so that we may be less dependent than at present on foreign supplies. Prior to the outbreak of war the official statistics showed that we were producing only about one-fifth of the wheat we consumed. As the war came in August our homegrown supply was at its maximum, and the Board of Agriculture was able to issue a reassuring report as to the quantities in hand. But the shortage of available shipping has so affected the amounts of imported wheat that the demand has exceeded the supply, and in consequence prices have risen.

The production of wheat on a large scale in this country is by no means a simple matter. There are, broadly speaking, three factors, soil and climate, economic conditions, and labour, each of which has to be considered separately.

The most fundamental way of increasing the amount of wheat is to increase the yield per acre, and this can be done by either (a) improving the soil conditions, or $(b)$ introducing new varieties capable of better growth than those already in use.

The improvement of soil conditions is brought about by increasing the supply of plant nutrients, i.e. artificial fertilisers, by cultivation, and in other ways. Before the war the world's consumption of artificial fertilisers was increasing more rapidly than the supply, so that prices were going up; this was particularly true of nitrogenous fertilisers. During the war farmers have had a demonstration of the value of artificial fertilisers, which will probably lead to a larger consumption after the war. The whole trend of the activities of the educational and advisory staffs of the agricultural colleges and other institutions is in this direction. The newer agriculture in other countries also calls for more fertilisers: Japan, Australia, India, Africa, and Java are all importers of artificial fertilisers from Europe. It seems reasonable to anticipate, therefore, a considerable increase in the consumption of these fertilisers provided the supply is forthcoming, and one of the most important and most hopeful problems for the future is to ensure these supplies.

Better cultivation of the land requires better implements, but, above all, a better understanding of what cultivation does to the soil. Research in this direction is in hand at Rothamsted and elsewhere, but considerably more work is wanted on the study of implements and better opportunities for testing them.

The production of new varieties is another method by which yields may be increased. Soil and climatic conditions are capable of only a certain degree of modification, and it is clearly an advantage when the plant-breeder can meet the soil-improver half-way and produce a new plant better adapted than the old ones to the conditions actually obtaining. The work of the newer school of botanists seems full of promise in this direction; Prof. Biffen at Cambridge has already done a good deal, and the move of the Botanical Section of the British Association in appointing a special committee to consider this matter is a welcome sign of their intention to attack an important and highly interesting problem.

Another method for increasing the amount of home-grown wheat is to increase the area devoted to wheat either by taking in more land or by displacing some other crop already grown. Increasing the area of land is a favourite suggestion, but one fraught with numerous difficulties. The non-technical tourist walking over Dartmoor or

$$
\text { NO. 2458, VOL. 98] }
$$


Bagshot Heath is very apt to ask why this land is not reclaimed and made to grow crops. The question is not a new one. Whenever war has come prices have gone up, and in the old days, when there was less regard than now for public rights, people did not hesitate to enclose any land they thought suitable. The result is that our present waste lands have already been picked over several times, and therefore only the least desirable are left. Some of the land reclaimed in older periods of high prices has gone out of cultivation and could be brought back, but not all of the wastes are suitable, even if the very troublesome questions of public and other rights could be solved. A survey is badly needed of the wastes of the country; there are no statistics giving the information needed, and the loose talk about millions of acres of reclaimable land does not forward matters.

A more promising direction is to displace other and less valuable crops by wheat. Of these the most suitable is grass. Mr. Middleton recently showed that the German farmer feeds $7^{\circ}$ to 75 people per roo acres, while the English farmer feeds 40 to 45 only. It is not that the German gets so much more per acre, but that he has twothirds of his land in arable and only one-third in grass; while in England only one-third is arable and two-thirds is grass. Now grassland only produces about one-half as much food as arable. Many suggestions have been made for breaking up grassland. From the theoretical point of view this course is eminently sound. Unfortunately, there are grave economic objections. Grassland involves so little risk that it serves as a useful counterpoise to the larger risks of arable farming. It is of no use disguising the fact that farmers are not breaking up their grassland, and they meet every appeal with the statement that they cannot afford to do so. Various ways of meeting their difficulty have been suggested, but as they are mainly political they need not be discussed here.

This leads up to the economic factor. The farmer grows wheat for profit and not for pleasure, and when he is presented with a scheme for increasing" his yield his first question is, "Will it pay?" There is a limit set by soil, climate, and the plant itself, beyond which growth will not go. Our average wheat crop is $3^{2}$ bushels; a good farmer will look for 40 , in specially good seasons he may get $5 \circ$, but 60 bushels would represent a crop he had heard about but probably never seen. There being this limit to the amount producible, the main economic factor becomes the selling price. This is " complicated by the circumstance that wheat takes many months to produce, so that a rise in price does not induce a corresponding increase in the supply unless there is good reason to suppose that the increase will recur when the new crop is ready. Thus wheat is now $78 s$. per quarter, but this circumstance is not so powerful an incentive to an increase in area as it looks, because the wheat sown now will not be ready for sale until October or November, 1917, by which No. $245^{8}$, vol. 98$]$ time the price may be down to $30 s$, or even less. On the other hand, a run of low prices is a powerful deterrent for a long time. For years after the low prices of the early 'nineties farmers were very shy of growing wheat, and even up to the time of the war they were always afraid that low prices might come back.

Lord Milner's Committee proposed to overcome this difficulty by guaranteeing a minimum price to farmers, and thus using a supply even though in particular years the arrangement might involve a eharge on the national finances. It is argued that in this case the community would be better off than it is on present lines, where pricès sometimes fall very low and sometimes rise considerably higher. Of course, such a guarantee on the part of the community would involve a corresponding obligation on the part of the farmer, and the precise adjustment of these obligations affords scope for considerable political ingenuity.

The labour question is partly, but not entirely, bound up with the question of cost. The gross return per acre obviously fixes the amount of money the farmer can afford to spend on the crop, and of this only a portion can be allotted to labour. So long as the work is done, it is immaterial to the consumer whether labour's share goes to few or to many. From the labourer's point of view, however, this is very important; and as he does not like low wages, and as, further, he can often get much higher pay on the railway or other work, no small difficulty has arisen on farms where the efficiency of the labourer is low, and where, therefore, a good many labour-hours are required to produce an acre of crop.

This difficulty can be met by increasing the labourer's efficiency and so reducing the number of labour-hours. Machinery can be made to help in two ways: by doing a given piece of work with fewer men and by doing it in less time. In either case the labourer gains more money, unless the machine swallows up the whole. It is certain that considerable possibilities are opened up here. To take a single instance: On an ordinary farm the ploughing of an acre of land takes one man and two horses a whole day, or on some soils it needs a man, a boy, and three horses. In the writer's district the usual rate of pay for such work is about $3^{s}$. for the man, and normal prices and yields would not justify much more. But with a motor-plough one man can plough three or four acres per day. The cost of the implement is more than that of a plough and two horses, so that more has to be allowed for interest and depreciation. But there is still a sufficient balance left to justify the payment of a higher wage to the man, and therefore to induce him to remain on the land.

It is impossible to foretell the extent of the revolution caused by the internal-combustion engine. It has given us motor-cars and aeroplanes, and thus revolutionised travel by land and by air, and now it is being applied on the farm. For the moment it is being treated as if it were a strange kind of horse; and simply hitched on to the old horse implements. But it is conceivable 
that some new kind of implement altogether is needed in order to get the best out of this engine. Experiments are sadly needed on this problem. None of the agricultural experiment stations are taking the matter up at present because of the cost and other difficulties, but it needs to be done.

None of these difficulties are insuperable; the various research institutions which now exist in this country can attack the technical problems with considerable hope of success. The economic problems, however, require different treatment; above all they require to be approached from the point of view of the business man rather than from that of the party politician.

The first thing needed is to decide the importance of home-grown food: whether it is vitally important to the community or simply highly desirable. If it is only desirable, things can be left as they are, because agencies are already at work that will take the farmer so far as he feels disposed to go with present high costs of production and the risk of a slump in prices in I9I7. If; on the other hand, a large supply of homegrown food is vitally important, then our present methods must be modified so as to aim at maximum-crop production regardless of possible low prices in I9I7. At present the farmer is invited to bear the whole of this risk, and with the best will in the world many feel that he cannot do so; it is lack not of patriotism, but of capital that bars the way. The remedy might, and possibly would, involve making agriculture a controlled industry, but, at any rate, it would enable big unified schemes of crop production to be put into operation.

E. J. RusSELl.

THE JEWELRY TRADE IN WAR-TIME.

THE jewelry trade is very largely one of luxury, and consequently serves as an extremely sensitive indicator of the kind of weather the barque of State has encountered. In the bright days of prosperity people are apt to buy jewels : in the dark days of adversity they are no less apt to sell or pawn them. It is not surprising that at the outbreak of war even the most optimistic of jewellers were filled with the gloomiest forebodings as to the fate the future held in store for their business unless hostilities were soon brought to a satisfactory close. The war has, however, lasted far longer than was anticipated at the beginning by all save a few with exceptional depth of knowledge, and it is possible now to ascertain how far those forebodings were fulfilled.

The question, "What is the state of the jewelry trade in days of war?" may, as regards the United States and, to some extent, Great Britain, be answered from the report on the "Production of Precious Stones for the year I9x 5 ," which, as in former years, has been contributed to Mineral Industry ${ }^{1}$ by the well-known gem-expert, Dr. G. F. Kunz. The answer agrees with what is within common knowledge. The exceptional prosperity which the war has brought to areas engaged in

1 Vol. xxiv., pp. 59r-6r3, ror6. (New York: McGraw-Hill Book Company, Inc. ; London: Hill Publishing Co., Ltd.)

No. 2458 , VOL. 98] the manufacture of munitions is reflected in the trade in precious stones done there. Thus, we read that in May, I9I6-Dr. Kunz does not adhere rigidly to the year with which he is supposed to deal-upwards of five million dollars' worth of precious stones were imported into the United States-nearly three times the amount in the corresponding month of the previous year; in fact, all records were broken, even for the "boom" period of I906.

Again, as regards our own country, it is stated :--

It is worth noting as one of the curious effects of the war in London trade that the present demand for cheap diamond rings, such as are sold by East End jewellers, is phenomenally large. This is due to the exceptionally high wages earned by many British workers in the special industries, and also to their inclination toward free spending of their money. On the other hand, the demand for the larger diamonds has fallen off in England, since the wealthy classes have suffered a very considerable decline of income, due to industrial derangement and, above all, to heavy taxation. In Birmingham also the trade in low-priced diamond rings is exceedingly brisk.

Whether the picture thus outlined is strictly true for Great Britain as a whole we question. We believe that there is a great shortage of labour, not only owing to the requirements of the Army, but because so many of the skilled workers have been drafted into factories, their training having been found to fit them for many of the delicate operations in the manufacture of munitions. Nevertheless, the jewellers will perhaps go so far as to admit that things are very much better at this stage of the war than might have been anticipated beforehand.

Since diamonds are of such great importance for working the hard steels largely used in munitions, stringent precautions are taken by Great Britain to prevent stones, either cut or rough, from falling into hostile hands. Dr. Kunz prints the guarantees, to the effect that the diamonds will not be exported, directly or indirectly, to any country at war with Great Britain, which before the release of the package in question have to be signed before the British Consul-General by importers into the United States.

The report consists of two parts, each of about the same length, the first dealing with general points, and the second with particular species of precious stones. We notice in the former many interesting or curious points in addition to those already referred to. Thus, we are told that before the war much attention was being given in Paris, Vienna, and Berlin to colour-harmony in the wearing of jewels; apparently not in London-are we therefore to infer that a lower degree of taste prevails there? The lozenge-shape of cutting so popular for emeralds has been applied to diamonds with good results. The famous gem-district at Pala, San Diego County, California, has yielded magnificent crystals of rubellite weighing as much as 2 to $4 \mathrm{lb}$. each. Dr. Kunz boasts that the United States to-day possesses greater collections of precious stones than any other nation, and 